\title{
ANALISIS KELAYAKAN USAHA AGROINDUSTRI MIE SAGU DI KECAMATAN TEBING TINGGI KABUPATEN KEPULAUAN MERANTI
}

\author{
A Feasibility Analysis on Sago Noodles Agro Industry Businesses \\ in Tebing Tinggi District Kepulauan Meranti Regency
}

\author{
Tri Mukti dan Septina Elida \\ Fakultas Pertanian Universitas Islam Riau. Jl. Kaharuddin Nasution 113, Pekanbaru 28284 Riau \\ Telp. : 0761-72126 ext. 123, Fax : 0761-674681 \\ [Diterima: Juli 2017; Disetujui: Agustus 2017]
}

\begin{abstract}
Sago is the potential agricultural product in Kapulauan Meranti Regency and can be processed into various food product, including sago noodles. This study aims to find the sago noodles business profile, feasibility level viewed from financial and non financial aspect the sago noodles agroindustry in Tebing Tinggi District Kepulauan Meranti Regency. This research used survey method. Data were analyzed descriptively qualitative and quantitative. The non-financial aspects of the study consist of market, technical and legal aspects, while the financial aspects are analyzed by investment criteria. The results showed that sago noodles agroindustry entrepreneur including productive age with the average age of 46 years, education is still low that is 9 years (SMP) and experienced in trying sago noodle processing that is for 16 years. Sago noodle business is included in small-scale business and home industrial, processing of sago noodles using semi-modern and traditional technology. Non-financial feasibility of sago noodles on the market aspect and technical aspects is feasible to cultivate but the legal aspect is not yet feasible. Finally, sago noodles are feasible to be cultivated because they meet the investment feasibility criteria, with NPV value Rp 444,589,796,57, Net B / C 1,32, IRR 47\%, PB (payback period) 2 years 2 months. Based on switching value analysis, the business of sago noodle agroindustry is more sensitive to the $10 \%$ output price decrease compared to $10 \%$ input price increase.
\end{abstract}

Keywords: Agroindustry, Financial, Non Financial, Feasibility, Sago Noodle

\begin{abstract}
ABSTRAK
Sagu merupakan hasil pertanian unggulan di Kabupaten Kepulauan Meranti dan dapat diolah menjadi berbagai produk makanan, diantaranya mie sagu. Penelitian ini bertujuan untuk mengetahui profil usaha mie sagu, kelayakan usaha dilihat dari aspek finansial dan non finansial pada agroindustri mie sagu di Kecamatan Tebing Tinggi Kabupaten Kepulauan Meranti. Metode yang digunakan adalah survei. Data dianalisis secara deskripstif kualitatif dan kuantitatif. Aspek non finansial penelitian ini terdiri dari aspek pasar, teknis dan hukum, sedangkan aspek finansial dianalisis dengan kriteria investasi. Hasil penelitian menunjukkan pengusaha agroindustri mie sagu termasuk umur produktif dengan rata-rata umur 46 tahun, pendidikan masih rendah yaitu 9 tahun (SMP) serta berpengalaman dalam berusaha pengolahan mie sagu yaitu selama 16 tahun. Usaha mie sagu termasuk dalam usaha berskala kecil dan usaha rumah tangga, pengolahan mie sagu menggunakan teknologi semi modern dan tradisional. Kelayakan non finansial mie sagu pada aspek pasar dan aspek teknis layak untuk diusahakan namun pada aspek hukum belum layak. Secara finansial mie sagu layak untuk diusahakan karena memenuhi kriteria kelayakan investasi, dengan nilai NPV Rp 444.589.796,57, Net B/C 1,32, IRR 47\%, PB (payback period) 2 tahun 2 bulan. Berdasarkan analisis switching value usaha Agroindustri mie sagu lebih sensitive pada penurunan harga output $10 \%$ dibandingkan dengan kenaikan harga input $10 \%$.
\end{abstract}

Kata Kunci: Agroindustri, Finansial, Non Financial, Kelayakan, Mie Sagu 


\section{PENDAHULUAN}

Agroindustri merupakan kegiatan pasca panen produk pertanian yang didalamnya terdapat proses transformasi, pelestarian untuk menghasilkan produksi setengah jadi atau produk jadi dengan penekanan produk makanan. Tanaman sagu (Metroxylon sp) cukup potensial untuk dikembangkan sebagai bahan baku yang dapat diproses menjadi bahan pangan dan bahan industri (Timisela, 2006). Pati sagu dapat diolah menjadi berbagai produk organis tradisional, antara lain: mie, papeda, sinoli, ongol-ongol, sagu lempeng, sagu gula, sagu tumbuh, bubur ne, sagu mutiara, bagea dan lainnya.

Kabupaten Kepulauan Meranti merupakan daerah potensial penghasil sagu di Indonesia (Bintoro, 2009). Hampir disemua kecamatan tersebar tanaman sagu. Luas lahan tanaman sagu pada tahun 2015 di Kabupaten Meranti mencapai $50.514 \mathrm{Ha}$ dengan total produksi tanaman sagu sebesar 287.349 ton, dan petani yang terlibat dalam usahatani sagu mencapai 7.484 KK. Perkebunan sagu ini umumnya dikelola oleh rakyat dan hanya ada satu perusahaan swasta. Perkebunan milik rakyat yang memproduksi sagu terbanyak adalah Kecamatan Tebing Tinggi Timur dengan jumlah produksi sebanyak 71.942 ton, sedangkan yang memproduksi sagu terendah adalah Kecamatan Rangsang Barat dengan jumlah produksi sagu sebanyak 1.595 ton.

Potensi sagu yang besar di Kabupaten Meranti berdampak pada tingginya produksi sagu yang turut mendukung keberadaan kilang sagu di beberapa Kecamatan di Meranti. Kilang sagu berfungsi untuk mengolah tanaman sagu menjadi sagu basah atau tepung sagu. Kilang sagu sebagian besar dikelola oleh rakyat setempat. Sagu merupakan produk unggulan untuk pengembangan agroindustry (Elida S., 2017). Penduduk setempat mengolah tepung sagu menjadi bermacam-macam makanan dalam skala industri kecil dan rumah tangga (Indrawati \& Caska 2015). Keberadaan kilang sagu sebagai penyedia bahan baku industri sagu dimanfaatkan masyarakat Tebing Tinggi untuk mengembangkan industri yang berbahan baku sagu yaitu industri pangan. Salah satu industri pangan yang dikembangkan masyarakat Tebing Tinggi adalah agroindustri mie sagu. Tebing Tinggi merupakan daerah yang memproduksi mie sagu terbanyak $(52,17 \%)$ di Kabupaten
Kepulauan Meranti, yang tersebar di Desa Banglas, Gang Pusara, Desa Alahair dan desa lain yang terletak di Kecamatan Tebing Tinggi. Banyaknya jumlah pengusaha mie sagu di daerah ini karena Tebing Tinggi terletak di Selat Panjang yang merupakan ibu kota Kabupaten Kepulauan Meranti, sehingga usaha industri lebih menguntungkan untuk dikembangkan pada daerah tersebut dibandingkan dengan kecamatan lain.

Upaya peningkatan nilai tambah sagu membutuhkan investasi yang cukup besar, baik mendirikan ataupun mengembangkan usaha, hal ini juga terjadi pada pengolahan mie sagu. Investasi yang terlibat tidak hanya uang saja tetapi memerlukan sumber daya yang lainnya. Adanya peluang produk yang dijadikan sebagai makanan khas Kepulauan Meranti yang diminati baik masyarakat Riau maupun wisatawan yang datang ke Riau, membuat usaha ini memiliki prospek untuk dikembangkan, hal ini menjadikan pentingnya dilakukan analisis kelayakan terhadap usaha pengolahan mie sagu di daerah ini. Pendirian atau pengembangan usaha ini memerlukan analisis yang dapat menghindari atau menanggulangi risiko yang mungkin terjadi di masa yang akan datang (Gittinger, 1986).

Penelitian ini bertujuan menganalisis kelayakan usaha agroindustri mie sagu di Kecamatan Tebing Tinggi Kabupaten Kepulauan Meranti.

\section{METODE PENELITIAN}

Penelitian ini menggunakan metode survei. Penelitian dilaksanakan pada Desember 2016 sampai Mei 2017 di Kecamatan Tebing Tinggi Kabupaten Kepulauan Meranti Propinsi Riau. Lokasi penelitian dipilih secara sengaja (purposive) dengan pertimbangan karena daerah ini merupakan salah satu penghasil mie sagu terbanyak di Kabupaten Kepulauan Meranti. Sampel yang diteliti sebanyak 6 pengusaha mie sagu yang terpilih melalui Purposive sampling dengan penentuan kesamaan tahun berdiri usaha agroindustri mie sagu

\section{Analisis Data}

Data dianalisis secara deskripstif kualitatif dan kuantitatif melalui analisis kriteria investasi dan uji sensitivitas. Metode kualitatif disajikan dalam bentuk deskriptif untuk mengetahui aspek non finansial yang meliputi 
aspek pasar, aspek teknis dan aspek Hukum. Menurut Nurmalina et al. (2014) aspek pasar mempelajari tentang proyeksi permintaan, penawaran dan Program pemasaran meliputi empat aspek bauran pemasaran (marketing mix) yaitu produk (product), harga (price), distribusi (place), dan promosi (promotion). Adapun beberapa faktor yang diperlukan dalam menilai aspek teknis ini yaitu lokasi bisnis, tata letak (layout), proses produksi, (Nurmalina et al. 2014) , sedangkan menurut Nurmalina,dkk (2009) menyatakan aspek hukum diperlukan untuk mengidentifikasi bentuk badan usaha yang akan digunakan. Hal ini akan terkait dengan kekuatan hukum dan konsekuensinya, dan mempelajari jaminan-jaminan yang dapat disediakan bila akan menggunakan sumber dana berupa pinjaman, berbagai akta, sertifikat, serta izin.

\section{Kelayakan Finansial Agroindustri Mie Sagu}

Analisis kelayakan aspek finansial meliputi Net Present Value(NPV), Internal Rate of Return(IRR), Benefit Cost Ratio(B/C Ratio), dan Payback Periode(PBP), analisa menggunakan program Microsoft Excel dengan melakukan estimasi nilai investasi tahun berdiri ke tahun penyamaan 2017 dengan pendekatan inflasi sektoral dari masing-masing tahun berdiri perusahaan yang berbeda.

\section{Net Present Value (NPV)}

Suatu usaha dapat dikatakan layak jika jumlah seluruh manfaat yang diterimanya melebihi biaya yang dikeluarkan.(Nurmalina et al. 2014).

\section{$\Sigma$}

Keterangan:

$\mathrm{Bt}=$ Penerimaan yang diperoleh tahun ke-t

$\mathrm{Ct}=$ Biaya yang dikeluarkan pada tahun ke-t

$\mathrm{i}=$ Tingkat suku bunga/Discount Rate

$\mathrm{t}=$ Tahun $(1,2, \ldots, 10)$

$\mathrm{n}=$ Umur ekonomis proyek

Penilaian kelayakan finansial berdsarkan NPV yaitu :

NPV $>0=$ berarti secara finansial usaha agroindustri mie sagu layak untuk diusahakan

NPV $<0=$ berarti secara finansial usaha agroindustri mie sagu tidak layak untuk diusahakan

\section{Internal Rate of Return (IRR)}

IRR adalah tingkat suku bunga yang membuat nilai NPV proyek sama dengan nol.Nilai IRR didapat dengan menggunakan rumus sebagai berikut:

$\mathrm{IRR}=1+$

Keterangan:

I = Tingkat diskonto $15 \%$

$\mathrm{I}=$ Discount rate yang menghasilkan NPV positif $(\%)$

$\mathrm{i}^{\prime}=$ Discount rate yang menghasilkan NPV negatif $(\%)$

NPV = NPV yang bernilai positif

NPV' = NPV yang bernilai negatif.

\section{Net Benefit Cost Ratio (Net B/C Ratio)}

Rumus yang digunakan adalah sebagai berikut (Kadariah et al, 1999):

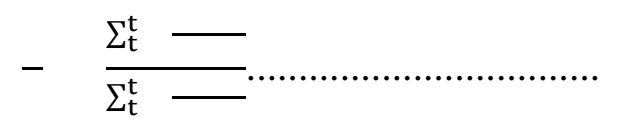

Keterangan :

$\mathrm{Bt}=$ manfaat yang diperoleh setiap tahun

$\mathrm{Ct}=$ biaya yang dikeluarkan setiap tahun

$\mathrm{t}=$ jumlah tahun (umur proyek)

$\mathrm{i}=$ tingkat suku bunga

Penilaian kelayakan finansial berdasarkan Net B/C yaitu:

Net $\mathrm{B} / \mathrm{C}>1=$ berarti proyek tersebut layak dan menguntungkan

Net $\mathrm{B} / \mathrm{C}<1=$ berarti proyek tersebut tidak layak dan tidak menguntungkan

\section{Payback Period}

Menurut Umar (2005) Payback period adalah suatu periode yang diperlukan untuk menutup kembali pengeluaran investasi dengan menggunakan aliran kas. Rumus PBP adalah sebagai berikut:

Keterangan :

$\mathrm{P}=$ waktu yang diperlukan untuk mengembalikan modal investasi

$\mathrm{I}=$ total investasi (rupiah)

$\mathrm{Ab}=$ total keuntungan bersih tiap tahun.

\section{Analisis Sensitivitas}

Nurmalina et al. (2014) menyatakan bahwa analisis switching value merupakan suatu variasi pada analisis sensitivitas. Hal ini menunjukkan bahwa apabila terjadi perubahan pada input dan output maka perubahan tersebut 
tidak boleh melebihi batas nilai switching value. Dengan kata lain apabila melebihi nilai pengganti tersebut, maka usaha menjadi tidak layak atau $\mathrm{NPV}<0$.

\section{HASIL DAN PEMBAHASAN}

\section{Karakteristik Pengusaha Mie Sagu}

Pengusaha mie sagu di Kecamatan Tebing Tinggi termasuk kelompok umur produktif dengan rata-rata umur 46 tahun. Sehingga dengan umur produktif, pengusaha memiliki peluang untuk mengembangkan usaha mie sagu lebih besar. Lama pendidikan selama 9 tahun. Rendahnya tingkat pendidikan pengusaha agroindustri mie sagu ini disebabkan karena tingkat ekonomi yang masih tergolong rendah dan kurangnya kesadaran atau motivasi untuk melanjutkan pendidikan ke tingkat yang lebih tinggi, rendahnya pendidikan sangat berpengaruh terhadap pengambilan keputusan dan penerapan inovasi serta kemungkinan risiko yang akan tejadi di kemudian hari. pengusaha memiliki rata-rata pengalaman berusaha selama 16 tahun, Dengan lamanya pengalaman dalam berusaha akan meningkatkan percaya diri dalam berusaha yang akan berdampak pada meluasanya pasar yang akan kuasai.

\section{Kelayakan Non Finansial Agroindustri Mie Sagu}

\section{Aspek Pasar Agroindustri Mie Sagu}

Usaha mie sagu ini dapat dikatakan memiliki peluang pasar yang cukup tinggi. Hal ini nampak dari produksi mie sagu yang setiap harinya selalu habis terjual. Permintaan mie sagu cenderung meningkat dengan berkembangnya bisnis kuliner di Provinsi Riau dan meningkatnya kesadaran masyarakat pada makanan sehat, bahkan mie sagu menjadi kuliner yang sangat digemari wisatawan manca Negara, karena memakan mie sagu tidak memberikan efek negatif bagi usus (Astawan, 2011).

Permintaan rata-rata mie sagu di Kecamatan Tebing Tinggi per tahun sebesar $342.298,24 \mathrm{~kg}$ sedangkan penawaran sebanyak $307,330 \mathrm{~kg}$.

Sehingga terdapat kelebihan permintaan dengan selisih permintaan dan penawaran tersebut sebesar 34.968,24 kg. Dengan demikian, masih ada peluang bagi perusahaan untuk terus meningkatkan produksinya agar dapat memenuhi permintaan pasar. Harga yang ditetapkan untuk produk mie sagu adalah $\mathrm{Rp}$ $3.000,00$ per 500 gram atau 0,5 kilogram. Penetapan harga dilakukan berdasarkan biaya yang dikeluarkan untuk bahan baku yang digunakan dengan berpatokan pada harga pasar yang berlaku dan perolehan keuntungan yang diharapkan. Pengusaha mie sagu mempunyai sales/distributor dalam mendistribusikan mie sagu. Namun, konsumen dapat mengunjungi langsung ke lokasi usaha untuk

membeli mie sagu secara eceran. Pihak distributor juga dalam melakukan pembelian dapat datang secara langsung ke pengusaha atau pemesanan via telepon kemudian pihak perusahaan mengirim barang ke tempat tujuan. Saluran distribusi mie sagu di Kecamatan Tebing Tinggi dapat dilihat pada Gambar 1.

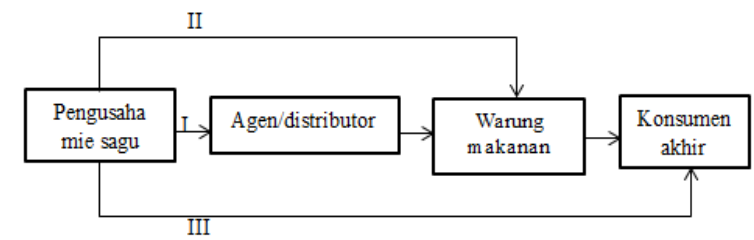

Gambar 1. Saluran Pemasaran Mie Sagu di Kecamatan tebing Tinggi

Dalam memasarkan mie sagu di Meranti terdapat tiga saluran. Pada saluran I perusahaan mengirimkan produk ke distributor atau pihak distributor mengambil sendiri mie sagu. Kemudian distributor menjual ke toko, pasar, warung menjual ke konsumen langsung. Jangkauan distributor dalam memasarkan mie sagu berada di berbagai wilayah seperti Pekanbaru, Bengkalis, Dumai. Pada saluran II, pemilik warung makanan biasanya mengambil mie sagu dari pengusaha mie sagu. Kemudian dari pemilik warung makanan sagu diolah menjadi makanan siap dikonsumsi sehingga sampai ke konsumen akhir. Saluran III merupakan saluran dimana perusahaan menjual produk mie sagu kepada konsumen secara langsung atau tanpa menggunakan perantara. Perusahaan melayani konsumen secara langsung di tempat usaha pembuatannya.

\section{Aspek Teknis Agroindustri Mie Sagu}

Penentuan lokasi merupakan hal yang sangat penting dalam pendirian suatu usaha. Pengusaha memanfaatkan dapur di rumahnya untuk dapat melakukan kegiatan produksi. Letak rumah pengusaha yang tidak jauh dari 
toko harian dan warung makanan mempermudah pengusaha untuk membeli bahan baku dan menjual mie sagu yang telah diproduksi. Berdasarkan segi fasilitas, listrik sudah tersedia dengan baik. instalasi air belum tersedia dengan baik karena kondisi air di tempat usaha tidak dapat digunakan, hal ini terbukti dengan warna mie sagu menjadi coklat bila memproduksi menggunakan air tanah. Ruangan produksi terbagi menjadi beberapa bagian, yaitu bagian penyimpanan bahan baku tepung, bagian mesin-mesin produksi dan bagian pengemasan. Kegiatan pengolahan mulai dari pengadukan bahan, penggilingan dan pengemasan dilakukan dalam satu ruangan yang sama. Setelah proses selesai, produk ditimbang dan dikemas, kemudian siap untuk didistribusikan.

Teknologi dalam pengolahan agroindustri mie sagu di Kecamatan Tebing Tinggi menggunakan peralatan tradisional dan semimodern. Mesin-mesin yang digunakan dalam pembuatan mie sagu dari mesin adonan (dough mixer) dan mesin press adonan (sheeting). Mesin adonan dan mesin pencetak didapatkan memalui bantuan yang diberikan Dinas Perindustrian setempat. Sedangkan untuk proses pengolahan lainnya dilakukan dengan cara manual yang peralatannya dibeli menggunakan uang pribadi pengusaha. Proses pengolahan mie sagu membutuhkan waktu \pm 11 jam yang mencakup menggongseng, mengadon, memipihkan, pengukusan, penirisan, pencetakan hingga pembungkusan mie sagu. Secara lebih lengkap proses pengolahan mie sagu di Kecamatan Tebing Tinggi disajikan pada gambar 2.

Berdasarkan hasil analisis aspek teknis, usaha produksi mie sagu dapat dikatakan layak untuk dilakukan. Hal ini karena, lokasi usaha yang berada di sekitar kilang sagu sehingga mendukung kelancaran proses produksi karena dekat dengan sumber bahan baku utama yaitu tepung sagu. Selain itu, lokasi yang strategis ini juga mendukung kemudahan dalam melakukan proses distribusi produk kepada para pemesan. Hal lain yang juga mendukung kelayakan usaha ini dari segi aspek teknis yaitu ketersediaan fasilitas dan kemudahan dalam transportasi

\section{Aspek Hukum Agroindustri Mie Sagu}

Aspek Hukum pada penelitian ini dikatakan layak bila terdapat dokumendokumen usaha yaitu Badan Hukum, Tanda Daftar Perusahaan (TDP), NPWP (Nomor Pokok Wajib Pajak), Surat Izin Usaha(SIU), Izin Domisil (ID), Izin Mendirikan Bangunan, Bukti Diri (KTP atau SIM), dan izin-izin lainnya. Sedangkan perizinan lain yang dibutuhkan terutama bagi usaha berbasis pangan yaitu adanya sertifikasi dari Badan Pengawas Obat dan Makanan (BPOM), Dinas Kesehatan (DK) dan sertifikasi halal (Sertifikat Halal). Pengusaha mie sagu di Kecamatan Tebing Tinggi sudah memiliki izin usaha tapi masih di tingkat desa, namun yang terdata pada Badan Penanaman Modal dan Pelayanan Usaha terpadu hanya $33,32 \%$. Hal ini terjadi karena ketidak pedulian dari pengusaha mie sagu walaupun dari instansi terkait telah memberi kemudahan dan informasi.

Pengusaha saat ini hanya berfikir untuk memproduksi mie sagu sebanyak-banyaknya dan menjual sebanyak-banyaknya tanpa memikirkan tentang surat izin usaha. Pengusaha yang memiliki surat izin usaha adalah pengusaha yang aktif mengikuti seminar dan memikirkan keberlanjutan usaha yang dijalani. Padahal bila seluruh pengusaha melengkapi izin usaha maka pasar yang akan di kuasai akan semakin luas dan tidak ada keraguan konsumen untuk membeli mie sagu serta tidak akan ada kekhawatiran masalah yang akan terjadi di masa yang akan datang.

Berdasarkan hasil analisis aspek hukum, usaha mie sagu di Kecamatan Tebing Tinggi ini masih belum layak untuk dijalankan. Hal ini karena pengusaha masih banyak yang belum memiliki izin usaha dari pihak manapun. Usaha mie sagu ini tidak memiliki kekuatan secara hukum sehingga dikhawatirkan akan menimbulkan masalah di kemudian hari.

\section{Kelayakan Finansial}

Kondisi finansial suatu usaha dilihat dari pengeluaran dan pemasukan. Sebelum menghitung penilaian kriteria investasi, terlebih dahulu diproyeksikan. Pengolahan mie sagu dalam penelitian ini diproyeksikan sepuluh tahun kedepan berdasarkan umur ekonomis aset. 

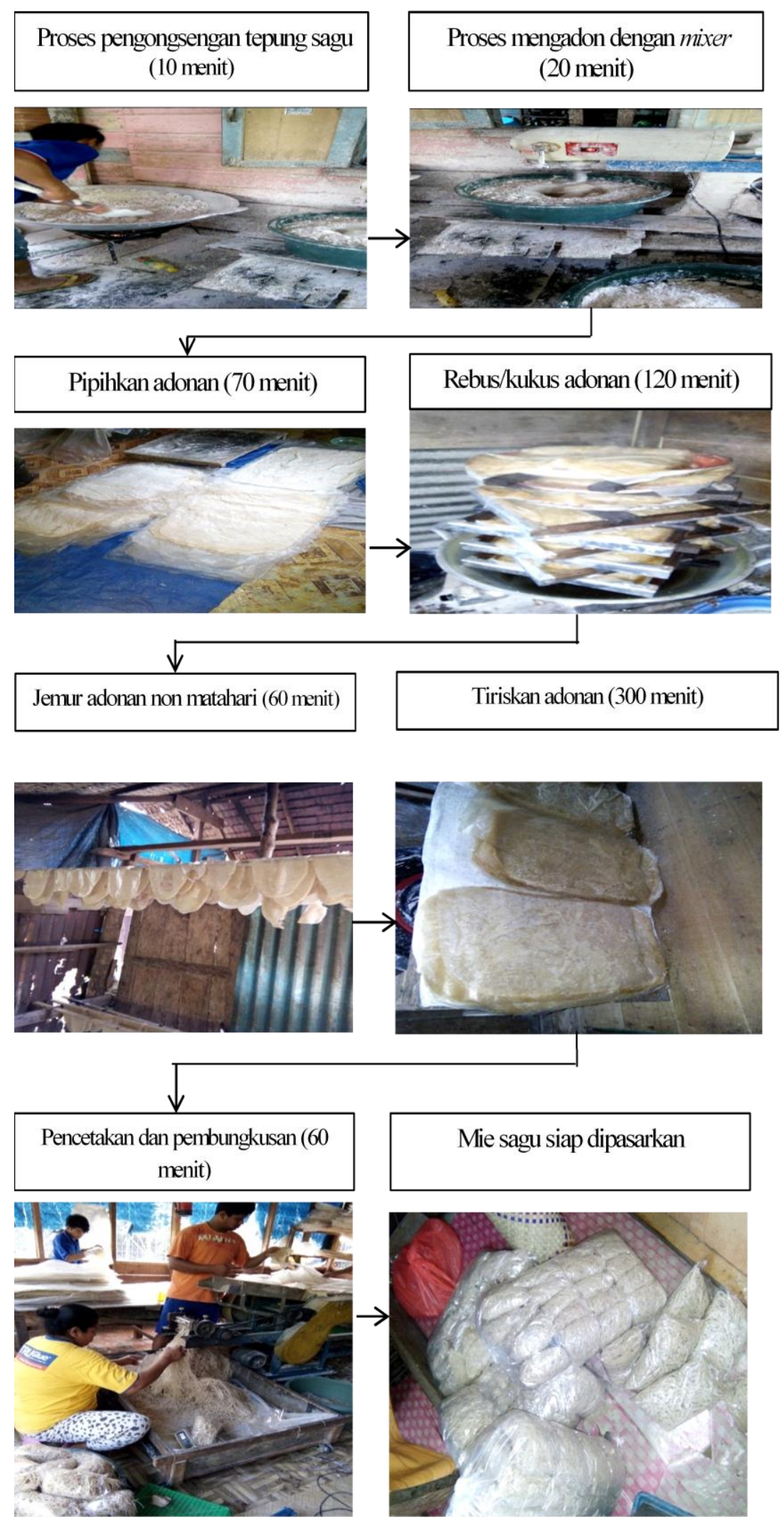

Gambar 2. Skema Pembuatan Mie Sagu di Kecamatan Tebing Tinggi 


\section{Analisis Outflow Agroindustri Mie Sagu}

Komponen biaya yang dikeluarkan oleh usaha pengolahan mie sagu mencangkup biaya investasi dan biaya operasional. Biaya investasi dikeluarkan pengusaha mie sagu di Kecamatan Tebing Tinggi diawal tahun usaha berupa investasi tanah, investasi bangunan dan investasi mesin dan peralatan. Adapun komponen investasi berupa alat atau teknologi yang digunakan dengan umur ekonomis kurang dari umur usaha (10 tahun) harus dilakukan reinvestasi. Peralatan yang akan dilakukan reinvestasi adalah kuali besar, pelempeng, nampan kotak, kayu pengukus, ember sedang, baskom besar, sendok nasi, tutup pengukus, regulator, baskom sedang, bambu, gayung, plastik dan lainnya yang memiliki nilai ekonomis kurang dari 10 tahun.

Tabel 1. Rata-rata biaya investasi dan operasional pengusaha agroindustri mie sagu di Kecamatan Tebing Tinggi

\begin{tabular}{rrr}
\hline Tahun & $\begin{array}{r}\text { Rata-rata Biaya } \\
\text { Investasi (Rp) }\end{array}$ & $\begin{array}{c}\text { Rata-rata Biaya } \\
\text { Operasional (Rp) }\end{array}$ \\
\hline 2016 & 316.764 .389 & 113.236 .573 \\
2017 & 8.547 & 127.128 .035 \\
2018 & 1.657 .383 & 152.005 .852 \\
2019 & 2.455 .014 & 162.593 .820 \\
2020 & 7.682 .909 & 182.063 .753 \\
2021 & 7.276 .262 & 205.529 .820 \\
2022 & 6.507 .570 & 232.177 .350 \\
2023 & 15.670 .080 & 262.445 .514 \\
2024 & 3.184 .042 & 296.834 .565 \\
2025 & 8.947 .640 & 336.333 .334 \\
\hline
\end{tabular}

Pada Tabel 1 rata-rata penggeluarkan biaya investasi terbesar adalah tahun 2016 (tahun 1). Hal ini karena mesin dan peralatan yang digunakan diasumsikan dibeli pada tahun 1 sedangkan tahun berikutnya adalah pembelian barang reinvestasi. Pada biaya operasional dari tahun ke tahun mengalami kenaikan. Hal ini terjadi karena setiap peralatan dan bahan yang digunakan dalam proses produksi mie sagu diasumsikan mengalami inflasi sesuai dengan jenis barang dan bahan yang digunakan. Inflasi yang digunakan berupa inflasi industri pengolahan sebesar 2,56\%, penyediaan akomodasi makan dan minum sebesar $14,00 \%$, pengadaan listrik dan gas sebesar $10,59 \%$ dan pengadaan air sebesar $3,07 \%$. Biaya satuan yang dikeluarkan dalam biaya operasional adalah sama kecuali tepung sagu karena setiap pengusaha membeli tepung sagu dengan merek yang berbeda dan di tempat yang berbeda sehingga menimbulkan perbedaan harga satuan. Perbedaan dalam memilih merek tepung sagu terjadi karena masing-masing pengusaha mie sagu memiliki standar kualitas yang berbeda dalam memproduksi mie sagu. Perbedaan harga tepung sagu berkisar antara $\mathrm{Rp} 5000-\mathrm{Rp}$ $6000 / \mathrm{kg}$. Biaya satuan yang memiliki harga yang sama adalah: tenaga kerja $\mathrm{Rp} 35.000 /$ hari (9 jam kerja), Listrik $\mathrm{Rp} 791,00$, air $\mathrm{Rp}$ 150/liter, plastik kemasan Rp 74,4.

\section{Analisis Inflow Agroindustri Mie Sagu}

Komponen biaya yang diterima oleh pengusaha mie sagu adalah Pendapatan penjualan. Pendapatan penjualan diperoleh dari hasil kali antara total penjualan produk dengan harga jual. Untuk lebih jelas rincian penerimaan usaha mie sagu tersaji pada Tabel 2.

Tabel 2. Pendapatan Pengusaha Mie Sagu di Kecamatan Tebing Tinggi (Rp)

\begin{tabular}{cr}
\hline Tahun & \multicolumn{1}{c}{ Rata-rata } \\
\hline 1 & 190.080 .000 \\
2 & 216.691 .200 \\
3 & 247.027 .968 \\
4 & $281.611 .883,5$ \\
5 & $321.037 .547,2$ \\
6 & $365.982 .803,8$ \\
7 & $417.220 .396,4$ \\
8 & $475.631 .251,8$ \\
9 & $542.219 .627,1$ \\
10 & $618.130 .374,9$ \\
\hline
\end{tabular}

Penerimaan pengusaha mie terus meningkat dari tahun ke tahun karena setiap tahun harga mie sagu diasumsikan terjadi kenaikan sebesar $0,14 \%$ sesuai dengan tingkat inflasi penyediaan akomodasi, makan dan minuman yang terjadi di Kabupaten Kepulauan Meranti. Sedangkan tahun pertama lebih rendah dibandingkan tahun yang lainnya dikarenakan pada usaha agroindustri mie sagu diasumsikan membeli aset investasi pada tahun pertama.

\section{Kriteria Kelayakan Investasi Usaha Agroindustri Mie sagu}

Kelayakan usaha agroindustri mie sagu dapat dilihat melalui kriteria investasi, yaitu Net Present Value (NPV), Internal rate of Return (IRR), Net Benefit Cost Ratio (Net B/C), dan Payback Period . 
Tabel 3. Nilai hasil analisis dari kriteria penilaian investasi

\begin{tabular}{|c|r|r|}
\hline Kriteria & \multicolumn{1}{|c|}{ Nilai } & \multicolumn{2}{c|}{ Kesimpulan } \\
\hline NPV & Rp 444.589.796,57 & $>0$ \\
\hline Net B/C & 1,32 & $>1$ \\
\hline IRR & $47 \%$ & $>10 \%$ \\
\hline PP & 2 tahun 2 bulan & $<10$ tahun \\
\hline
\end{tabular}

Dalam penelitian ini variabel yang akan dibahas yaitu kenaikan harga input dan penurunan output. Kenaikan harga input yang dimaksud dalam penelitian ini adalah kenaikan sebesar $10 \%$ yang terjadi pada biaya investasi dan operasional yang digunakan dalam proses produksi. Sedangkan harga output diasumsikan mengalami penurunan harga mie sagu sebanyak $10 \%$. Penentuan kenaikan dan penurunan harga sebesar $10 \%$ dalam penelitian ini berdasarkan rata-rata tingkat inflasi yang terjadi di Kabupaten Kepulauan Meranti selaku Kabupaten dari Kecamatan Tebing Tinggi.

Berdasarkan uji sensitivitas baik kenaikan harga input maupun penurunan harga dan aspek teknis layak untuk diusahakan namun pada aspek hukum belum layak. Sedangkan berdasarkan kelayakan finansial usaha mie sagu layak untuk diusahakan dengan NPV Rp 444.589.796,57>0, Net B/C $1,32>1$, IRR $47 \%>15 \%$, PB 2 tahun 2 bulan $<10$ Tahun. Usaha agroindustri mie sagu ini lebih sensitive pada penurunan harga output dibandingkan dengan kenaikan input

Dalam penelitian ini disarankan pengusaha melengkapi surat-surat yang berhubungan dengan perizinan usaha, terutama yang melekat pada produk seperti BPOM, sertifikat halal, sehingga memenuhi kreteria kelayakan, dan juga untuk meningkatkan kualitas usaha diharapkan partisipasi pengusaha dalam seminar/pelatihan yang dilakukan oleh akademisi/swasta/instansi terkait.

\section{DAFTAR PUSTAKA}

Alfons, J.B., R. Senewe, M. Pesireron dan J.

Tabel 4. Hasil analisis sensitivitas usaha pembuatan mie sagu

\begin{tabular}{|c|c|c|c|c|c|c|}
\hline Kondisi & Persentase & NPV(Rp) & $\begin{array}{c}\text { Net } \\
\text { B/C }\end{array}$ & $\begin{array}{c}\text { IRR } \\
(\%)\end{array}$ & PP & Kelayakan \\
\hline $\begin{array}{c}\text { Tanpa kenaikan \& } \\
\text { penurunan }\end{array}$ & - & $444.589 .796,57$ & 1,32 & $47 \%$ & $\begin{array}{c}2 \text { tahun } 2 \\
\text { bulan }\end{array}$ & Layak \\
\hline Kenaikan Input & $10 \%$ & $306.236 .813,33$ & 1,20 & $35 \%$ & $\begin{array}{c}2 \text { tahun } 4 \\
\text { bulan }\end{array}$ & Layak \\
\hline $\begin{array}{c}\text { Penurunan Harga } \\
\text { Output }\end{array}$ & $10 \%$ & $261.777 .833,67$ & 1,19 & $34 \%$ & $\begin{array}{c}2 \text { tahun 5 } \\
\text { bulan }\end{array}$ & Layak \\
\hline
\end{tabular}

output sebesar $10 \%$ usaha agroindustri mie sagu di Kecamatan Tebing Tinggi layak dilakukan.

\section{KESIMPULAN DAN SARAN}

1. Pengusaha agroindustri mie sagu termasuk umur produktif dengan rata-rata umur pengusaha yaitu 46 tahun, pendidikan masih rendah dengan rata-rata lama pendidikan selama 9 tahun(SMP) serta sudah berpengalaman dalam berusaha pengolahan mie sagu yaitu 16 tahun. Usaha mie sagu termasuk dalam usaha berskala kecil dan usaha rumah tangga, pengolahan mie sagu menggunakan teknologi semi modern dan tradisional.

2. Kelayakan non finansial mie sagu di Kecamatan Tebing Tinggi dari aspek pasar
Tolla, 2004. Identifikasi Potensi, Kendala dan Peluang Pengembangan Sagu di Maluku. Laporan Akhir Kajian Sistem Usahatani Sagu (Metroxylonspp.) di Maluku, T.A. 2003.

Astawan, M. 2008. Membuat Mi dan Bihun. Penebaran Swadaya. Jakarta

Austin J. 1992. Agroindustrial Project Analysis Critical Design Factors: EDI Series in Economic Development. Baltimore: John Hopkins Univ. Press

Bintoro, H.M.H. 2008. Bercocok Tanam Sagu. Online pada: http://www.bppt.go.id. Diakses 4 Agustus 2016.

Elida, S. 2017. Pemetaan Pertanian Potensial Dalam Pengembangan Agroindustri Unggulan Di Kabupaten Kepulauan Meranti.Jurnal Agrotech, 3(1): 72-87. 
Gittinger J.P. 1986. Analisa Ekonomi Proyek-proyek Pertanian. Edisi kedua. Jakarta: UI-Press. Jakarta.

Indrawati H., Caska, 2015, Financial Models for Sago Cake Makers in Supporting the Acceleration of Family Economic Improvement, Mediterranean Journal of Social Sciences, 6 (6) : 310-318.

Louhenapessy J.E. 2010. Sagu Harapan dan Tantangan. Jakarta. Bumi Aksara

Kadariah. 1988. Evaluasi Proyek Analisis Ekonomis. Jakarta. Fakultas Ekonomi, Universitas Indonesia.

Kasmir, Jakfar. 2003. Studi Kelayakan Bisnis Ed ke-2. Jakarta. Prenada Media Group

Nurmalina R, Tintin S, Arif K. 2009. Studi Kelayakan Bisnis. Bogor. Institut Pertanian Bogor.

Nurmalina, Sarianti, dan Karyadi. 2009. Studi Kelayakan Bisnis. Departemen Agribisnis, Fakultas Ekonomi dan Manajemen, Institut Pertanian Bogor.

Nurmalina R, T Sarianti, Feryanto. 2012. Kelayakan industri kecil bioetanol berbahan baku molasses di Jawa Tengah. Jurnal Manajemen dan Agribisnis.

Pasaribu,A.M. 2012. Perencanaan dan Evaluasi Proyek Agribisnis.Makassar: HasaniddinUniversity Press
Simatupang TM. 1997. Pemodelan Sistem. Bandung. Teknik Industri Institut Teknologi Bandung

Soekartawi. 2000. Pengantar Agroindustri. Jakarta. Raja Grafi ndo Persada

Suliyanto. 2010. Studi Kelayakan Bisnis. Yogyakarta. Penerbit Andi Tresnaprihandini Y. 2006. Formulasi Strategi Pengembangan Usaha Kerupuk Udang dan Ikan Pada Perusahaan Candramawa di Kabupaten Kendal. Skripsi. Fakultas Ekonomi dan Manajemen. Institut Pertanian Bogor. [tidak dipublikasikan]

Sutawi. 2002. Manajemen Agrobisnis. Malang. UMM Press.

Timisela, N. R., (2006), Analisis Usaha Sagu Rumahtangga dan Pemasarannya, Jurnal Agroforestri, 1 (3): 57 - 64.

Umar. 2007. Studi Kelayakan Bisnis. Jakarta : Gramedia Pustaka

Udayana, G. B. 2011. Peran Agroindustri dalam Pembangunan Pertanian. Diakses 28 juli 2016. 
